\title{
Influence of saddle type upon the incidence of lower back pain in equestrian riders
}

\author{
S Quinn, S Bird
}

\begin{abstract}
Objective-To investigate the possible influences of saddle type on the incidence of "lower back pain" in a cross section of equestrian riders.

Methods-108 equestrian riders completed a questionnaire concerning their riding habits and whether they suffered from lower back pain. In particular they were asked whether they used a traditional style/general purpose saddle (GP) or a deep seated/Western style saddle $(W)$.

Results $-48 \%$ of the riders reported suffering from lower back pain, the incidence being higher in the GP saddle users $(66 \%)$ than in $W$ saddle users $(23 \%)(P<0.001)$. Female riders had a higher incidence of lower back pain than males, $58 \%$ v $27 \%$ $(P<0.005)$. When the genders were analysed separately for the effect of saddle type, males using the GP and $W$ saddles had a $33 \%$ and $6 \%$ incidence of lower back pain respectively, while females using the GP and $W$ saddles had a $72 \%$ and $33 \%$ incidence. The highest incidence of lower back pain occurred in the GP saddle users who had been riding for more than 15 years $(P<0.07)$. The data also indicated a possible tendency for there to be more low back pain among riders using a short stirrup length. No other factors were found to affect the incidence of lower back pain.
\end{abstract}

Conclusions-The difference in the incidence of lower back pain between the users of the two saddle types may be due to the additional comfort, cushioning, postural positioning, and stability offered by the design of the deep seated saddle. The results suggest that, while a deep seated saddle is not suited to all equestrian activities, where possible its use should be considered because of its effect in reducing the risk of lower back pain.

(Br F Sports Med 1996;30:140-144)

Key terms: equestrian injuries; lower back pain; saddle type

Department of Sport Science, Canterbury Christ Church College, North Holmes Road, Canterbury CT1 1QU,

United Kingdom

$S$ Quinn, research

student

$S$ Bird, principal lecturer

Correspondence to:

DrS Bird.

Accepted for publication

22 August 1995 traumatic type and have included fatalities, fractures, spinal and head injuries. While these may be of greatest concern because of their injury, with approximately 18 injuries per injuries studied have generally be caused by falls or kicks. They are therefore of the severity, general correspondence with sports injury practitioners and members of the riding fraternity indicates that they are relatively rare when compared with the incidence of certain overuse injuries. Of these the most commonly reported complaint among equestrian riders is "lower back pain", which appears to afflict a significant proportion of riders regardless of age or experience. However, despite its widespread occurrence, little is known about its causes and even less about how it may be prevented. Indeed it is often regarded as an inevitable consequence of riding and is accepted as an occupational hazard, without any further consideration as to its prevention.

The suggested pathologies of lower back pain include damage to the musculature, ligaments, disks, and vertebrae in the lumbar and sacroiliac regions. ${ }^{7}$ This is believed to be caused by the riding action which results in a number of compressive forces being transmitted through the rider's vertebral column. In addition to this, the riding action can also cause both hyperflexion and hyperextension of the vertebral column, especially when performing the "sitting trot". These movements and forces are therefore considered to be the major contributors to lower back pain injury. However, while it is widely accepted that the major cause of lower back pain is the riding action, there are several related variables which may affect its occurrence. For example, there are certain variations in the riding position and the saddle type used by equestrian riders which may be key factors affecting the stresses upon the vertebral column while riding, and hence the risk of injury.

\section{THE RIDING POSITION}

In studies investigating the biomechanics of the "classic" riding action it has been found that the thigh at the top of the hip is generally positioned at an angle of 30 to 40 degrees to the horizontal. This causes a natural flattening of the lumbar lordosis, ${ }^{8-11}$ a factor which many authorities associate with excessive stress in this region. Indeed in this posture there is considerable additional lumbar vertebral and disk loading, of up to $65 \%$ of an individual's body weight. This additional stress is likely to cause significant compression of the vertebral disks, thereby increasing the risk of damage. The loss of lumbar lordosis is also likely to increase the stress on the muscles and ligaments of the lower back while they work to maintain the body's posture and centre of balance.

While Auvinet ${ }^{12}$ considered this to be the natural riding position, others ${ }^{5}{ }^{10}$ have disputed 
it and advocate the use of a longer stirrup length with which the thigh would be positioned at a 45 degree angle to the horizontal. In support of this they have suggested that this would permit the natural maintenance of the lumbar lordosis, which has an inherent capacity to absorb the compression of the riding action, and would therefore not increase any muscular or ligamentous tensions in the lower back or hip regions. It would also reduce the amount of pelvic retroversion, which can be as much as 20 degrees when using a short stirrup length. ${ }^{13} 14 \mathrm{~A}$ further result of this would be to facilitate a seated position in which the centre of gravity of the rider was in closer alignment with that of the horse, thereby promoting a more natural riding movement. This could lessen some of the unwanted stresses in this region by reducing the need for constant postural corrections.

These suggestions indicate that a longer stirrup length would provide a less stressful riding posture, which could reduce the incidence of lower back pain.

\section{SADDLE TYPES}

To be most effective a saddle must provide maximum comfort, security, and control. It must also assist in the positioning of the rider's body in relation to the horse's centre of balance. Most equestrian professionals agree that the saddle should be a precision instrument ${ }^{15}$ which must be suited to the needs of both the horse and rider.

For the purpose of this study saddle types were categorised into two broad classes: (1) the traditional (classic English type), and (2) the deep seated saddles. The former category include dressage, general purpose, jumping,

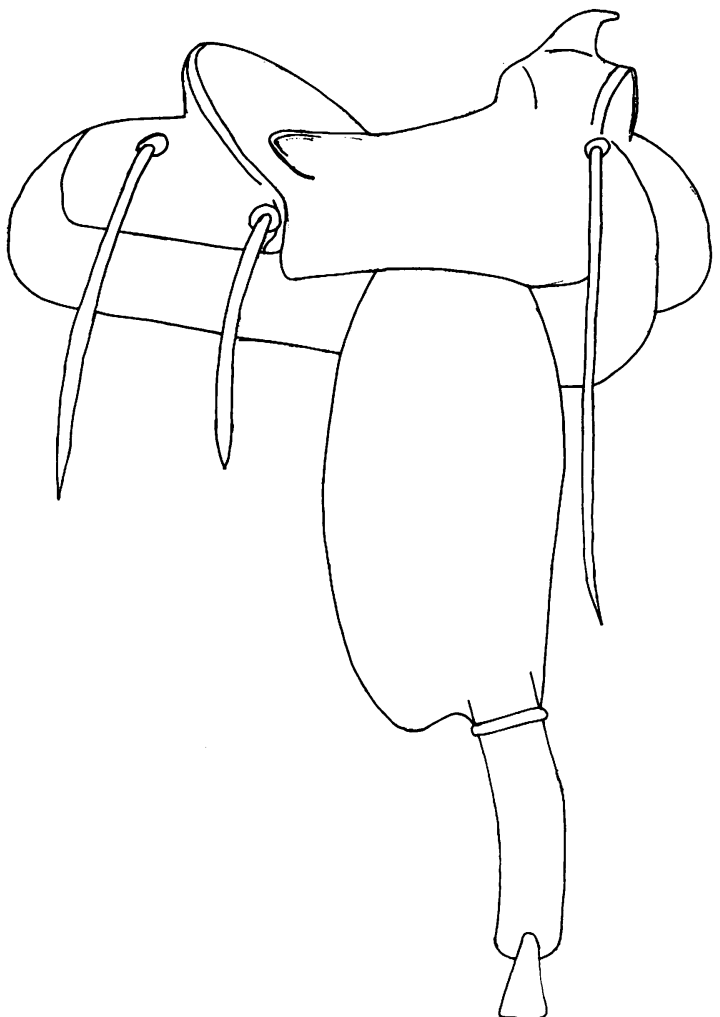

and hunting saddles. The deep seated saddles include the Western and long distance riding saddles.

The differences between the traditional and deep seated saddles relate to the activities for which they were designed. While there are many different riding disciplines in Britain, each of which differs in the demands made of the rider and for which a specifically designed saddle may be available, many riders use one saddle for all of them. This is usually the general purpose saddle, which is designed for diversity. The aim of this saddle is to be all things to all riders, and its popularity is due to its relative inexpense and its ability to be used in a diversity of riding activities. Variations are available, with dressage and jumping varieties. However, it is argued by saddlers and equestrian experts that the general purpose saddle does not allow the rider to develop the correct riding posture for each individual discipline, as it does not fulfil the exact requirements of any one of these but is a compromise and therefore cannot be a precision instrument. The general purpose saddle is a variation of the traditional saddle, which was designed for hunting and had a relatively flat seat, with a low pommel and cantor (figure). The saddle flaps form a D shape and the stirrup bar is positioned towards the pommel. This permits a shorter stirrup length so that the rider can adopt the forward riding position needed for jumping.

The deep seated saddles were designed for use in activities such as cattle and sheep herding. Their features provide the rider with maximum comfort, stability, and security during long periods of riding. The characteristics of these saddles are a higher pommel (horn), a deeper seat, a higher cantour, straight

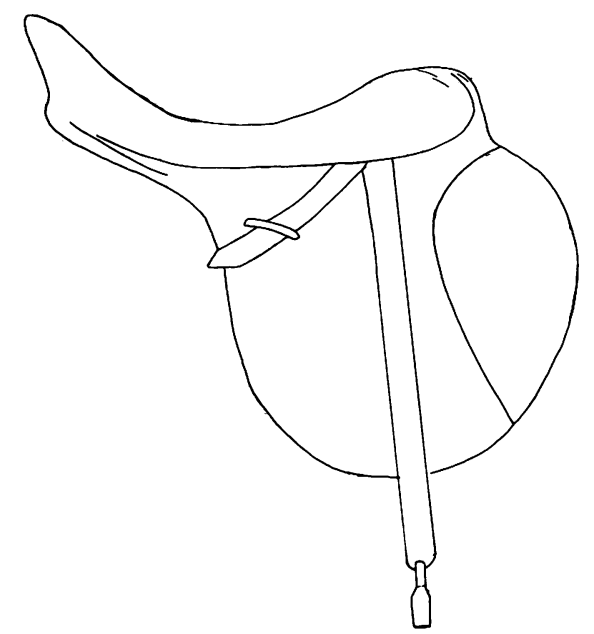


saddle flaps, and a stirrup bar which is positioned further back, thus allowing a longer stirrup length. These features allow the rider to assume a more upright position, reducing the amount of pelvic tilt and helping to maintain the natural lumbar lordosis. Since this facilitates the natural capacity of the vertebral column to absorb compressive forces it should be more effective in reducing the incidence of stress in this region. The saddle is also larger in size and therefore the compressive forces can be absorbed through the larger surface area, thereby reducing the stresses experienced in the vertebral column of the rider.

The enhanced security of the deep seated saddle assists the rider in maintaining the correct position in the saddle, reducing the need for postural readjustments and therefore the stress on the vertebral column. Conversely, the reduced security of the traditional British saddle results in a tendency for the rider (especially novices) to constantly readjust their seated position in an attempt to maintain the correct riding posture. Additionally, if used with a short stirrup length - which is the norm - it also places the vertebral column in an unnatural position in which to make these adjustments, thereby increasing the stresses on the structures of the vertebral column. ${ }^{10}$

Thus, based upon the opinions of a number of authorities there are indications that the use of the traditional saddle with a short stirrup length is more likely to result in lower back pain than the use of a deep seated saddle with a longer stirrup length. The aim of this study was therefore to investigate the possible influences of these two factors upon the incidence of lower back pain in a cross section of equestrian riders.

\section{Methods}

We used a questionnaire in which we asked riders about their riding habits, number of years riding, the types of equestrian activities in which they participated, saddle types and stirrup length used, preference for the rising or sitting trot, and their standard of riding. They were also asked about other equestrian related duties in which they participated, such as stable duties, along with personal details relating to age, gender, occupation, and in the case of females whether they suffered from lower back pain during menstruation.

Table 1 Subject details. Means, ranges and standard deviations are shown where appropriate

\begin{tabular}{|c|c|c|c|c|c|c|}
\hline & \multicolumn{3}{|c|}{$\begin{array}{l}G P(n=65) \\
(\text { males } n=18 \text {; females } n=47)\end{array}$} & \multicolumn{3}{|c|}{$\begin{array}{l}W(n=43) \\
\text { (males } n=16 \text {; females } n=27)\end{array}$} \\
\hline & $\bar{x}$ & $(S D)$ & range & $\bar{x}$ & $(S D)$ & range \\
\hline $\begin{array}{l}\text { Age (years) } \\
\text { Males } \\
\text { Females }\end{array}$ & $\begin{array}{l}33 \cdot 5 \\
38 \cdot 5 \\
31 \cdot 7\end{array}$ & & $\begin{array}{l}18-56 \\
18-56 \\
18-52\end{array}$ & $\begin{array}{l}44 \cdot 6 \\
47 \cdot 1 \\
43 \cdot 1\end{array}$ & & $\begin{array}{l}18-79 \\
18-68 \\
18-79\end{array}$ \\
\hline $\begin{array}{l}\text { Years riding } \\
\text { Males } \\
\text { Females }\end{array}$ & $\begin{array}{l}15 \cdot 9 \\
11 \cdot 5 \\
17 \cdot 5\end{array}$ & $\begin{array}{l}(9 \cdot 4) \\
(9 \cdot 9) \\
(8 \cdot 9)\end{array}$ & $\begin{array}{l}3-40 \\
3-40 \\
4-40\end{array}$ & $\begin{array}{l}25 \cdot 2 \\
19 \cdot 9 \\
28 \cdot 4\end{array}$ & $\begin{array}{l}(16 \cdot 7) \\
(18 \cdot 5) \\
(15 \cdot 0)\end{array}$ & $\begin{array}{l}3-68 \\
3-49 \\
3-68\end{array}$ \\
\hline $\begin{array}{l}\text { Number of hours riding per week } \\
\text { Males } \\
\text { Females }\end{array}$ & $\begin{array}{l}8 \cdot 8 \\
8 \cdot 2 \\
9 \cdot 0\end{array}$ & $\begin{array}{l}(8 \cdot 2) \\
(7 \cdot 2) \\
(8 \cdot 6)\end{array}$ & $\begin{array}{l}1-52 \\
1-30 \\
1-52\end{array}$ & $\begin{array}{r}10 \cdot 4 \\
9 \cdot 6 \\
10 \cdot 9\end{array}$ & $\begin{array}{l}(9 \cdot 4) \\
(7 \cdot 6) \\
(10 \cdot 4)\end{array}$ & $\begin{array}{l}1-54 \\
1-30 \\
1-54\end{array}$ \\
\hline $\begin{array}{l}\text { Body weight }(\mathrm{kg}) \\
\text { Males } \\
\text { Females }\end{array}$ & $\begin{array}{l}64 \cdot 2 \\
75 \cdot 0 \\
60 \cdot 3\end{array}$ & $\begin{array}{l}(11 \cdot 1) \\
(8 \cdot 8) \\
(9 \cdot 1)\end{array}$ & $\begin{array}{l}47 \cdot 6-95 \cdot 3 \\
63 \cdot 5-95 \cdot 3 \\
47 \cdot 6-92 \cdot 1\end{array}$ & $\begin{array}{l}69 \cdot 3 \\
73 \cdot 2 \\
67 \cdot 1\end{array}$ & $\begin{array}{l}(10 \cdot 3) \\
(6 \cdot 6) \\
(11 \cdot 4)\end{array}$ & $\begin{array}{l}52 \cdot 7-101 \cdot 6 \\
60 \cdot 3-82 \cdot 6 \\
52 \cdot 7-101 \cdot 6\end{array}$ \\
\hline
\end{tabular}

GP, general purpose saddle; $W$, Western saddle.
In the questionnaire the riders were asked to indicated whether they suffered from any lower back pain. "Lower back pain" was defined as pain in the lumbar and/or sacroiliac region and they were asked to indicate the site of the lower back pain on a diagram which was enclosed as part of the questionnaire. Details of the timing of the onset of lower back pain during and/or after riding gave an indication of its acute or chronic nature.

Riders were selected at random from local and national registers and contacted by post, or alternatively were given the questionnaire at nationally affiliated riding events. In total 600 riders were contacted, of whom 200 responded. Of these women who had had a baby within the last 12 months were excluded, as were any riders who had undergone abdominal surgery within the last 12 months, suffered from arthritis, had incurred a traumatic lower back injury within the last three years, suffered from persistent lower back pain or pain in the neck, shoulder, or thoracic region, or had not ridden in the last three years. All riders had to be over 18 years of age and to have been riding for a minimum of three years. This gave a usable sample of 108. These were then divided into two groups based upon the type of saddle they used: (1) traditional saddle users, $n=65$, all of whom primarily used the general purpose saddle (GP) and only used an alternative one, such as a dressage saddle, on rare occasions; and (2) deep seated saddle users, $n=43$, of whom all used the Western saddle (W). The responses of these two groups were then analysed and compared, using a variety of statistical tests. None of the riders had permanent lower back pain and all of those suffering from lower back pain believed it to be related to their riding.

\section{Results}

The personal details and riding habits of the two groups are summarised in table 1 . Overall the group using the Western saddles (W) were older, had been riding for longer, and were slightly heavier. However, no difference was found in the number of hours the two groups spent riding each week or the main riding activities in which they participated, indicating that they were closely matched for these variables.

Overall, $48 \%$ of the riders questioned reported suffering from lower back pain. The two groups were then compared for the incidence of lower back pain, the results of which are presented in table 2 , with a summary of the statistical analysis $\left(2 \times 2\right.$ contingency table $\chi^{2}$ analysis) for various factors summarised in table 3. These revealed the incidence of lower

Table 2 Incidence of lower back pain (LBP) in the two groups of riders

\begin{tabular}{|c|c|c|c|c|c|c|}
\hline & \multicolumn{3}{|l|}{$G P$} & \multicolumn{3}{|l|}{$W$} \\
\hline & Males & Females & Total & Males & Females & Total \\
\hline $\begin{array}{l}\text { LBP } \\
\text { No LBP } \\
\text { Total }\end{array}$ & $\begin{array}{r}8 \\
9 \\
17\end{array}$ & $\begin{array}{l}34 \\
13 \\
47\end{array}$ & $\begin{array}{l}42(66 \%) \\
22(34 \%) \\
64\end{array}$ & $\begin{array}{r}1 \\
15 \\
16\end{array}$ & $\begin{array}{r}9 \\
18 \\
27\end{array}$ & $\begin{array}{l}10(23 \%) \\
33(77 \%) \\
43\end{array}$ \\
\hline
\end{tabular}

GP, general purpose saddle; W, Western saddle. 
Table 3 Summary of the $\chi^{2}$ analysis of the frequency of lower back pain (LBP) $v$ no LBP. All analyses are in the form of $\chi^{2}$ tests using contingency tables

\begin{tabular}{|c|c|c|c|c|c|c|}
\hline \multirow{2}{*}{$\begin{array}{l}\text { Factors analysed for influence upon LBP } \\
\text { Saddle type } \\
\text { (GP } v \text { W) } \\
\text { (GP } v \text { W) } \\
(\text { GP } v \text { W) }\end{array}$} & \multirow{2}{*}{$\begin{array}{l}\text { Group }(s) \text { being analysed } \\
\\
\text { All riders (male and female) } \\
\text { Males } \\
\text { Females }\end{array}$} & \multicolumn{3}{|c|}{ Percentage incidence of $L B P$} & \multirow{2}{*}{$\begin{array}{r}x^{2} \\
18 \cdot 48 \\
6 \cdot 92 \\
10 \cdot 72\end{array}$} & \multirow{2}{*}{$\begin{array}{l}P \\
\\
<0.001 \\
<0.01 \\
<0.002\end{array}$} \\
\hline & & $\begin{array}{l}\text { GP } \\
66 \\
47 \\
72\end{array}$ & $\begin{array}{r}W \\
23 \\
6 \\
33\end{array}$ & & & \\
\hline $\begin{array}{l}\text { Gender } \\
\text { (male } v \text { female) } \\
\quad \text { (male } v \text { female) } \\
\text { (male } v \text { female) }\end{array}$ & $\begin{array}{l}\text { All riders (GP and W) } \\
\text { All GP riders } \\
\text { All W riders }\end{array}$ & $\begin{array}{r}M \\
27 \\
47 \\
6\end{array}$ & $\begin{array}{l}F \\
58 \\
72 \\
33\end{array}$ & & $\begin{array}{l}8 \cdot 69 \\
3 \cdot 54 \\
4 \cdot 13\end{array}$ & $\begin{array}{l}<0.005 \\
<0.007 \\
<0.05\end{array}$ \\
\hline $\begin{array}{l}\text { Hours riding per week } \\
\qquad \begin{array}{l}(<4 v 4-10 v>10) \\
(<4 v 4-10 v>10) \\
(<4 v 4-10 v>10)\end{array}\end{array}$ & $\begin{array}{l}\text { All riders (GP and W) } \\
\text { All GP riders } \\
\text { All W riders }\end{array}$ & $\begin{array}{l}<4 \\
54 \\
63 \\
36\end{array}$ & $\begin{array}{l}4-10 \\
49 \\
71 \\
22\end{array}$ & $\begin{array}{l}>10 \\
43 \\
62 \\
14\end{array}$ & $\begin{array}{l}0.93 \\
0.48 \\
1 \cdot 70\end{array}$ & $\begin{array}{l}>0.5 \text { (NS) } \\
>0.5 \text { (NS) } \\
>0.25 \text { (NS) }\end{array}$ \\
\hline $\begin{array}{l}\text { Age } \\
\qquad \begin{array}{l}(<40 v>40) \\
(<40 v>40) \\
(<40 v>40)\end{array}\end{array}$ & $\begin{array}{l}\text { All riders (GP and } \mathrm{W}) \\
\text { All GP riders } \\
\text { All W riders }\end{array}$ & $\begin{array}{l}<40 \\
63 \\
63 \\
23\end{array}$ & $\begin{array}{l}>40 \\
39 \\
71 \\
16\end{array}$ & & $\begin{array}{l}1 \cdot 28 \\
0 \cdot 31 \\
0 \cdot 30\end{array}$ & $\begin{array}{l}>0.25 \text { (NS) } \\
>0.5 \text { (NS) } \\
>0.5 \text { (NS) }\end{array}$ \\
\hline $\begin{array}{l}\text { Number of years spend riding } \\
\quad(<5 v 5-15 v>15) \\
(<5 v 5-15 v>15) \\
(<5 v 5-15 v>15)\end{array}$ & $\begin{array}{l}\text { All riders (GP and W) } \\
\text { All GP riders } \\
\text { All W riders }\end{array}$ & $\begin{array}{l}<5 \\
43 \\
57 \\
14\end{array}$ & $\begin{array}{l}5-15 \\
45 \\
47 \\
40\end{array}$ & $\begin{array}{l}>15 \\
49 \\
79 \\
22\end{array}$ & $\begin{array}{l}0 \cdot 27 \\
5 \cdot 55 \\
1 \cdot 15\end{array}$ & $\begin{array}{l}>0.5 \text { (NS) } \\
<0.07 \\
>0.5 \text { (NS) }\end{array}$ \\
\hline $\begin{array}{l}\text { Stirrup length } \\
\quad \text { (Long } v \text { short) }\end{array}$ & All GP riders & $\begin{array}{l}\mathrm{L} \\
59\end{array}$ & $\begin{array}{l}S \\
70\end{array}$ & & 0.84 & $>0.25(\mathrm{NS})$ \\
\hline
\end{tabular}

GP, general purpose saddle; W, Western saddle.

back pain to be nearly three times higher $(66 \%$ $v 23 \%)$ in the GP group $(\mathrm{P}<0.001)$. This difference was also apparent when the male and female results were analysed separately, with the incidence of lower back pain being $47 \% v 6 \%$ for male riders $(P<0.01)$ and $72 v$ $33 \%$ for female riders $(P<0.002)$ using the GP and $\mathrm{W}$ saddles respectively.

A $2 \times 2 \chi^{2}$ analysis of the relative incidence of lower back pain between females and males revealed approximately twice the incidence in female riders, $58 \% v 27 \%(\mathrm{P}<0.005)$. This difference was also apparent when the data for the two different saddle types were analysed separately. For the GP saddle users $47 \%$ of males compared with $72 \%$ of females reported suffering from lower back pain, while for the W saddle users lower back pain was reported by only $6 \%$ of male riders compared with $33 \%$ of female riders. This further confirmed the higher incidence of lower back pain with the GP saddle in both males and females, and the higher incidence of lower back pain in females with both saddle types.

The data were then analysed to see if any of the other recorded factors affected the incidence of lower back pain. Riders were divided into three categories according to the number of hours they spent riding each week. These were $<4,4-10$, and $>10$ hours. The incidence of lower back pain in these three groups was $54 \%, 49 \%$, and $43 \%$ respectively $(P>0.5)$ for the whole group (GP and W). When the data were analysed separately for GP and W riders, the relative incidence of lower back pain were $63 \%, 71 \%$, and $62 \%(P>P 0.5)$ for the GP riders and $36 \%, 22 \%$, and $14 \%(P>0.25)$ for the $\mathrm{W}$ riders. There was therefore no obvious link between the number of hours spent riding each week and the incidence of lower back pain.

The riders were then categorised according to the number of years they had been riding. The categorise used were $<5,5-15$, and $>15$ years. For the whole group (GP and W) the relative incidence of lower back pain were $43 \%, 45 \%$, and $49 \%$ respectively $(P>0.5)$, indicating no clear link between the incidence of lower back pain and the number of years spent riding. However, when the data for the GP and W riders were analysed separately, while no link was found with the $W$ group $(14 \%, 40 \%$, and $22 \%, P>0.5)$ a possible link was noted in the GP group, with $79 \%$ of those who had been riding for more than 15 years reporting lower back pain as opposed to only $57 \%$ and $47 \%$ of those who had been riding for less than 5 years and 5-15 years respectively $(\mathrm{P}<0.07)$.

The riders were then grouped into two categories according to age $(<40$ and $>40$ years). When the group as a whole (GP and W) was analysed, the incidence of lower back pain was $63 \%$ and $39 \%$ for the under and over 40 s respectively $(P>0.25)$, indicating no conclusive link between age and the incidence of lower back pain. Likewise, when analysed as separate groups, the relative incidence of lower back pain amongst the GP riders was $63 \% v$ $71 \%(P>0 \cdot 5)$, while for the $W$ riders it was $23 \%$ v $16 \%(\mathbf{P}>0.5)$

The data were then analysed to investigate the influence of stirrup length upon the incidence of lower back pain. Of the riders who used the $\mathrm{W}$ saddle, only one rode with short stirrups and therefore no further analysis was possible with this group. Of the GP riders, $58 \%$ used short stirrups and $42 \%$ used long stirrups. Of these, $70 \%$ of the short stirrup users and $59 \%$ of the long stirrup users suffered from lower back pain. This trend may support the ideas of some authorities who suggest that the use of short stirrups contributes to the incidence of lower back pain. However, when analysed statistically using a $2 \times 2 x^{2}$ test a value of only 0.84 was obtained $(P>0 \cdot 25)$.

\section{Discussion}

The results of the questionnaire revealed a very high incidence $(48 \%)$ of low back pain among equestrian riders. This should be a cause for concern to the riding fraternity and practitioners who deal with the problem. Any factor which could reduce the incidence of this injury 
must therefore be given serious consideration. One of these factors appears to be the type of saddle used by equestrian riders. In this study a difference in the incidence of lower back pain was found between riders using the GP and W style saddles. Those using the general purpose saddles suffered nearly three times the rate of lower back pain, the incidence of which appeared to be unrelated to factors such as number of hours spent riding per week, age, or the type of riding activity undertaken.

Female riders experienced a greater incidence of lower back pain than male riders, while for both genders the incidence of lower back pain was higher with the GP saddle.

The incidence of lower back pain was highest in riders who had been using the GP saddle for more than 15 years. Since this trend was not apparent in the W group it could indicate that the additional stresses caused by the use of the GP saddle could have a cumulative effect in causing lower back pain over a period of years, a factor which was not apparent in the riders using the $\mathrm{W}$ saddle.

The influence of stirrup length on the incidence of low back pain was inconclusive. The data indicated a possible trend for a higher incidence of low back pain among riders who used a short stirrup length. This would support the findings of other authorities who suggest that a short stirrup length places the vertebral column in a position in which it is more vulnerable to stress and injury. However, the statistical analysis of this factor did not enable any firm conclusions to be made in support of these ideas.

The results of this investigation therefore indicate that one of the major factors influencing the incidence of lower back pain in equestrian riders is the type of saddle used. The lower incidence among those using the deep seated saddles may be related to the additional support, postural position, and cushioning offered by its design. Therefore in the context of reducing the incidence of lower back pain among equestrian riders it may be desirable to advocate the use of deep seated saddle. However, we appreciate that this is not a practical suggestion for all riders, as its design is unsuited to certain equestrian activities. We therefore suggest that the use of a deep seated saddle should be considered by any rider wishing to pursue general equestrian activities that do not require a specialist saddle. Also, since the results indicated a possible cumulative effect of using a GP saddle, riders who do pursue specialist riding should consider the use of a deep seated saddle on occasions when a specific saddle type is not required.

Finally, further research is required to investigate whether changing from a GP to a W style saddle can alleviate lower back pain in riders who are currently afflicted with it.

1 Lloyd RG. Riding and other equestrian injuries: considerable severity. Br f Sports Med 1987;21:22-4.

2 Whitlock MR, Whitlock J, Johnston B. Equestrian injuries: a comparison of professional and amateur injuries in Berkshire. Br f Sports Med 1987;21:25-6.

3 Firth J. Equestrian injuries. In: Schneider RC, Kennedy JC, Plant MI, eds. Sports injuries, mechanisms, prevention and treatment, 1st ed. Baltimore: Williams and Wilkins,

4 Strong I, MacMillan R, Jennett B. Head injuries in accident and emergency departments at Scottish hospitals. Injury 1978;10:154-9.

5 Nicholl JP, Coleman P, Williams BT. Injuries in sports and exercise. Fact sheet publication. London: Sports Council, 1991.

6 DeBenedette V. People and horses: the risks of riding. Physician Sportsmed 1989;17:250-4.

7 Rashbaum RF. Soft tissue trauma in equestrian participation. In: Hochschuler SH, ed. The spine in sports. Philadelphia: Hanley and Belfus, 1990:180-91.

8 Mandal AC. The seated man. Copenhagen: Dafnia, 1985.

9 Akerblom B. Standing and sitting posture. Stockholm: Nordiska, Bokhandeln, 1948.

10 Keegan JJ. Alterations of the lumbar curve related to posture and seating. $\mathcal{F}$ Bone foint Surg $(\mathrm{Am})$ 1953;35A:589-603.

11 Griffiths M, Gustafsson A. A comparative study of lumbar biomechanics and sacroiliac joint mobility in horseback riders and non-riders. Bournemouth, England: AngloEuropean college of Chiropractic, 1987 [diploma thesis].

12 Auvinet B. La rachis du cavalier. Rhumatologie 1980; 32:85-9.

13 Von Gottwald A. Processes of movement during riding with special reference to movement of the spine. Deutsch Zeitschrift Fur Sportmedizin 1980;6:172.

14 Loch S. The classical seat. New York: Unwin Hyman, 1988. 15 Hartley Edwards E. The saddle in theory and practice.
London: J A Allen, 1990. 